\title{
Mineralogical data on bat guano deposits from three Romanian caves
}

\author{
Alexandra GIURGIU1* \& Tudor TĂMAŞ ${ }^{1,2}$ \\ ${ }^{1}$ Department of Geology, Babeș-Bolyai University, Kogălniceanu 1, 400084 Cluj-Napoca, Romania \\ 2“Emil Racoviţă” Institute of Speleology, Clinicilor 5, 400006 Cluj-Napoca, Romania
}

Received August 2013; accepted September 2013

Available online 14 October 2013

DOI: http://dx.doi.org/10.5038/1937-8602.58.2.2

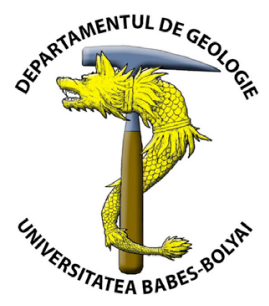

\begin{abstract}
Mineralogical studies performed on crusts, nodules and earthy masses from the Romanian caves Gaura cu Muscă, Gaura Haiducească and Peștera Zidită have revealed the presence of three different phosphate associations. The minerals have been identified by means of X-ray diffraction, scanning electron microscopy, and energy dispersive spectroscopy. Five phosphates have been identified in the samples, with hydroxylapatite the only common mineral in all the three caves. Brushite, taranakite, leucophosphite and variscite are the other phosphates identified. Associated minerals include gypsum, calcite, quartz, and illite-group minerals. Aside from differences in the lithology, the occurrences of the different phosphate minerals indicate variable $\mathrm{pH}$ and relative humidity conditions near or within the guano accumulations.
\end{abstract}

Keywords: guano, cave phosphate associations, Gaura cu Muscă, Gaura Haiducească, Zidită Cave, Romania

\section{INTRODUCTION}

Phosphate minerals are a common feature in caves containing bat guano accumulations, where they form as a result of the interaction of guano derived solutions with the cave bedrock or with secondary (chemical or detrital) cave deposits. Reviews of phosphate minerals occurring in caves were published by Hill and Forti (1997) and Onac and Forti (2011a). Up to now, more than 100 phosphate minerals have been identified in caves (Onac, 2012), five of which are considered as commonly occurring: hydroxylapatite, brushite, ardealite, taranakite and variscite (Hill and Forti, 1997; Onac, 2012). The mechanisms responsible for phosphate formation in caves include digestion, dissolution, double replacement and redox reactions (Onac and Forti, 2011b). When solutions percolating through guano deposits interact with the limestone bedrock, they usually produce Ca-rich phosphates (brushite and hydroxylapatite) (Hill and Forti, 1997). If clay minerals are present on the flowpath, minerals such as leucophosphite, taranakite, variscite etc. may form (Hill and Forti, 1997). Leucophosphite, variscite and taranakite are stable under acidic, wet conditions, whereas hydroxylapatite indicates an alkaline environment (Onac and Vereș, 2003; Onac, 2012). Moreover, phosphate alteration or dehydration processes may sometimes be at the origin of new minerals: if there is a decrease in humidity and an increase in temperature at the site, brushite and francoanellite may dehydrate to monetite and taranakite respectively (Hill and Forti, 1997; Onac and Vereș, 2003). In such conditions, the study of phosphate minerals may offer information about the environmental conditions.

The aim of this study was to describe the minerals from three Romanian caves containing bat guano accumulations: Gaura cu Muscă, Gaura Haiducească, and Zidită Cave, and the environmental conditions in which they have formed. Of these three caves, only Gaura cu Muscă was previously studied with respect to its mineralogy, and a phosphate association consisting of vashegyite, crandallite, and ardealite was described (Onac et al., 2006).

\section{CAVE SETTINGS, LOCATION AND DESCRIPTION}

The three caves studied are located in two different Romanian mountain massifs: Locvei Mountains, SW Romania (Gaura cu Muscă and Gaura Haiducească) and Metaliferi Mountains, W Romania (Zidită Cave) (Fig. 1).

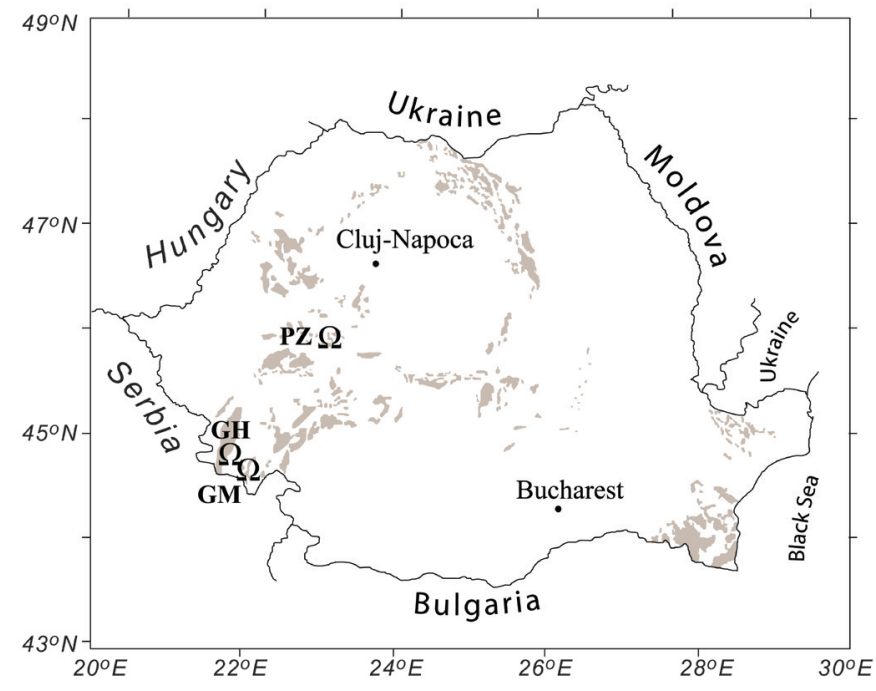

Fig. 1. Gaura cu Muscă (GM), Gaura Haiducească (GH), and Zidită (ZC) caves on the Romanian karst map. 
Gaura cu Muscă and Gaura Haiducească caves are formed in the karst rocks of the Reșiţa-Moldova Nouă Synclinorium, an area where limestones cover more than $800 \mathrm{~km}^{2}$ (Iurkiewicz, 2010). This sector includes parallel massifs separated by valleys or karstic plateaus (Bucur, 1997). Geologically, the synclinorium belongs to the Getic Domain, a structural unit of the South Carpathians (Balintoni, 1997; Balintoni et al., 2009). Limestone deposition in the area occurred discontinuously from the Triassic to the Lower Cretaceous.

Zidită Cave (also known as Mada or Dacilor) is located in the SE part of the Metaliferi Mountains, in the upper watershed of the Geoagiu River where the mesozoic limestones crop out as faulted karstified alignments or isolated blocks (Povară and Horoi, 1993; Orășeanu, 2010). The Geoagiu River flows into the Mada Gorges, separating the Balșa Tithonian limestone block (3 $\mathrm{x} 1.5 \mathrm{~km}$ ) in two massifs, Pleșa Mare (E) and Dosu (W) (Mantea and Tomescu, 1986; Cocean, 1988).

\section{Gaura cu Muscă Cave (GM)}

Gaura cu Muscă Cave (GM) opens in the Upper Jurassic limestones (Bleahu et al., 1976) from the left bank of the Danube, $3 \mathrm{~km}$ downstream the locality of Coronini, Caraș-Severin County (SW Romania). The entrance is located at $92 \mathrm{~m}$ asl and is easily reached following a footpath spotted right from the DN 57 road, built along the left side of the Danube Gorge, near the border of Romania and Serbia. This active cave was inhabited since the Hallstatt period and was fortified during the XV-XVI and XVIII -XIX centuries (Boroneant, 2000). The cave is $254 \mathrm{~m}$ long and was firstly mapped by Negrea and Negrea (1969) (Fig. 2a). The Dry Passage (40 m long) opens from the entrance, behind the fortification and contains clay sediments and wood fragments (Negrea and Negrea, 1979). The stream is flowing through the main gallery of the cave (the Water Passage) and deposits banks of gravel, sand and clay. In the Bats Room fresh guano accumulates due to the presence of a Myotis capaccinii colony (Coroiu, pers. comm.). The Water Passage is shortcut by a $\sim 20 \mathrm{~m}$ long fossil gallery (Bats Passage), which is flooded when the stream level is high. A sequence consisting of alternating guano and silt-clay layers is deposited on the floor of this gallery. Another fossil gallery (Clay Passage) is located towards the end of the cave and hosts a Rhinolophus euryale colony (Coroiu, pers. comm.). Mineralogical samples were collected from the Bats Room and Bats Passage and consist of ochre to dark brown earthy material interlayered within horizons of fossil guano.

\section{Gaura Haiducească (GH)}

Gaura Haiducească Cave (Fig. 2b) develops in the Lower Cretaceous limestones from the vicinity of the town of Moldova Nouă, Caraș-Severin County (SW Romania), at 488.5 asl and has two entrances, both located in Poiana Peșterii (Bleahu et al., 1976). It represents the underground capture of the Ogașul Găurii brook (Iurkiewicz et. al., 1996), which is reached by following the DC 49 road from the town of Moldova Nouă. Ceramic fragments discovered by Boroneant (2000) indicate that the cave has been known since the Neolithic period. The cave was explored and mapped on $1380 \mathrm{~m}$ and consists of three distinct parts (Iurkiewicz et al., 1996). The upstream part of the cave is represented by the Great Hall (Fig. 2b), a large entrance room (180 m long, $60 \mathrm{~m}$ large and $25 \mathrm{~m}$ high) covered with limestone blocks, moonmilk speleothems and small gours with cave pearls (Bleahu et al., 1976). The guano accumulations found in this sector are related to a Rhinolophus bat colony (Negrea and Negrea, 1979). The small

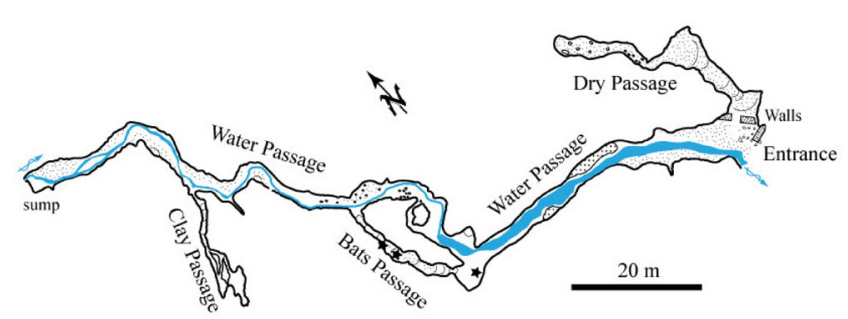

a

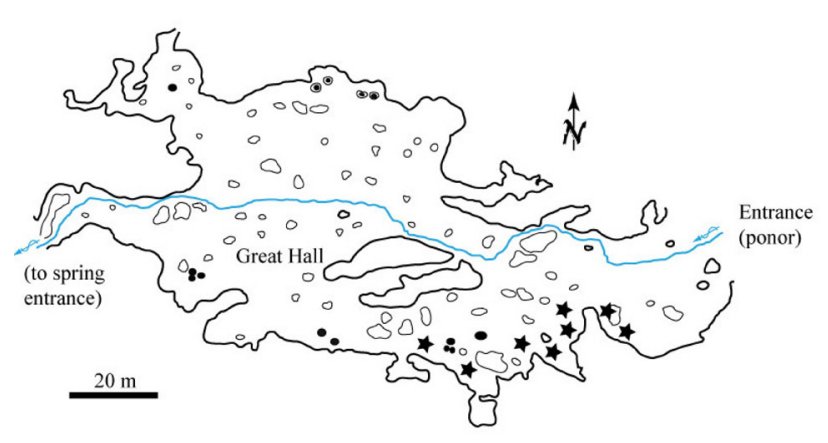

b

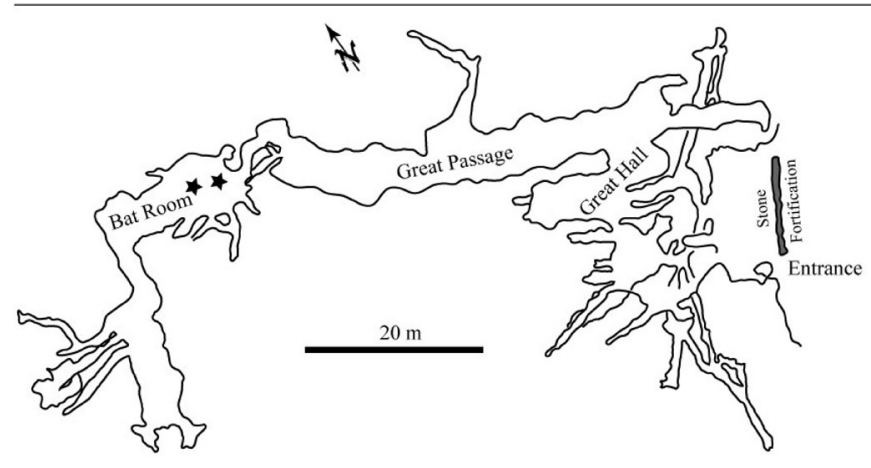

C

Fig. 2. Maps of the studied caves with location of samples (stars): a) Gaura cu Muscă (simplified from Bleahu et al., 1976); b) The Great Hall from Gaura Haiducească (simplified after Bleahu et al., 1976); c) Zidită Cave (map by Proteus Hunedoara Caving Club, used with permission).

median passage (Junction Passage) is only temporarily active, but may be completely occupied by water during floods. In the active Resurgence Passage downstream, another Rhinolophus bat colony is present (Bleahu et al., 1976). This passage leads to the spring entrance of the cave. The samples were collected from the southern slopes of the Great Hall, close to the upstream entrance, and consist of white to yellowish-brown nodules, lenses, and earthy aggregates within the guano sequence or at the contact with the clay sediments.

\section{Zidită Cave (ZC)}

Zidită Cave is located close to the Mada village from Hunedoara County (Romania). The cave opens at $410 \mathrm{~m}$ asl in the Pleșa Mare limestone massif. This cave was also used for defensive purposes in the medieval period, when its entrance was fortified with a wall, which is visible today.

Zidită Cave, mapped by Proteus Caving Club (Hunedoara, Romania), is a fossil maze with a total length of $547 \mathrm{~m}$ consisting of three main sectors: the Great Hall located right after the entrance, the Great Passage in the median part and the Bats Room towards the end of the cave (Fig. 2c). Limestone blocks and clay sediments are common in the entire cave, whereas active stalactites, small rimstone dams and calcite rafts are scarce and may be seen in the median passage. There are several guano accumulations in the 
cave: the largest (1.5 m thick) is located in the Bats Room and probably belongs to a Rhinolophus nursery colony. The material sampled for analyses consists of crusts formed on fallen limestone blocks at the contact with this large guano deposit.

\section{ANALYSIS METHODS}

The 52 mineralogical samples collected from the three caves were analyzed by means of X-ray diffraction, scanning electron microscopy, and electron dispersive spectroscopy. The X-ray diffractions were performed using two instruments: 1 . a Siemens D5000 diffractometer with $\mathrm{Cu} K \alpha$ radiation, (from Serveis Cientificotècnics, Universitat des les Illes Balears, Palma de Mallorca, Spain), operated at $40 \mathrm{kV}$ and $30 \mathrm{~mA}$. The step-scan data were continuously collected over the range of $5^{\circ}$ to $75^{\circ}$ $2 \theta$, using a step interval of $0.05^{\circ} 2 \theta$ with a counting time of 1 second per step, using silicon (NBS 640b) as internal standard. DiffracEVA (8.0) software with the PDF2 database was used to identify the minerals; 2 . a Bruker D8 Advance diffractometer with $\mathrm{Co} K \alpha$ radiation, $\mathrm{Fe} 0.01 \mathrm{~mm}$ filter and a one-dimensional detector, from the Department of Geology, Babeș-Bolyai University (ClujNapoca, Romania). The working parameters are $35 \mathrm{kV}$ and 40 $\mathrm{mA}$. The data were collected between $5^{\circ}$ and $64^{\circ} 2 \theta$ with a step interval of $0.02^{\circ} 2 \theta$ with counting time of $0.5 \mathrm{~s} / \mathrm{step}$. Corundum NIST SRM1976a served as internal standard and the DiffracEVA (2.1 ver.) program with the PDF2 database were used to identify the minerals.

Environmental scanning electron microscopy (ESEM) was performed on a Hitachi S-3400N equipped with a Bruker Energy Dispersive Spectroscopy (EDS) microanalyzer system from Serveis Cientificotècnics (Universitat des les Illes Balears, Palma de Mallorca, Spain).

\section{RESULTS}

The analyses of samples collected from the three caves have revealed the presence of five phosphate minerals: brushite, hydroxylapatite, leucophosphite, taranakite and variscite, along with gypsum, calcite, illite-group minerals and quartz.

Brushite $\left[\left(\mathrm{CaHPO}_{4} \cdot 2 \mathrm{H}_{2} \mathrm{O}\right)\right]$ is a phosphate belonging to the monoclinic crystal system and is isostructural with gypsum. This mineral occurs only in Zidită Cave as a whiteivory paste-like material, where the X-ray diffractions have shown its association with hydroxylapatite (Fig 3a.). Under ESEM, brushite crystals are tabular and flattened after the (010) face (Fig. 4). Similar associations consisting of brushite and hydroxylapatite were described, among others, by Fiore and Laviano (1991), Onac and Vereș (2003), Marincea et al. (2006), and Tămaș and Ungureanu (2010). Brushite is a common cave mineral, stable under acidic $(\mathrm{pH}<6)$ and damp conditions (Hill and Forti, 1997). It results from the reaction of the carbonate bedrock with the phosphoric acid derived from guano deposits (Fiore and Laviano, 1991). Frost and Palmer (2011) suggest the following reaction for brushite formation:

$$
\left(\mathrm{NH}_{4}\right)_{2} \mathrm{HPO}_{4}+\mathrm{Ca}^{2+}+2 \mathrm{H}_{2} \mathrm{O} \rightarrow \mathrm{CaHPO}_{4} \cdot 2 \mathrm{H}_{2} \mathrm{O}+2 \mathrm{NH}_{4}^{+} .
$$

The phosphate ion is derived from guano accumulations where it appears probably as a ammonium phosphate.

Hydroxylapatite $\left[\left(\mathrm{Ca}_{5}\left(\mathrm{PO}_{4}\right)_{3} \mathrm{OH}\right)\right]$, crystallizing in the hexagonal system, was identified in samples from all the three caves (Fig. 3a). It occurs as thin light- to dark-brown crusts on the limestone from the cave floors, walls or ceilings in association with: brushite (in Zidită Cave), taranakite and quartz (in Gaura cu Muscă) or with taranakite, gypsum, calcite and quartz (in Gaura Haiducească). The hydroxylapatite crystals are clustered in aggregates as revealed by the ESEM images (Fig. 5a). This mineral is generally formed at a pH above 6 due to the reaction of limestone with phosphatic solutions derived from guano (Fiore and Laviano, 1991; Onac and Vereș, 2003).

Leucophosphite $\left.\left[\mathrm{K}_{(} \mathrm{Fe}^{3+}\right)_{2}\left(\mathrm{PO}_{4}\right)_{2}(\mathrm{OH}) \cdot 2 \mathrm{H}_{2} \mathrm{O}\right]$ is a phosphate mineral crystallizing in the monoclinic system. The XRD and EDS analyses of the samples from Gaura cu Muscă Cave reveal the presence of this phosphate in association with taranakite, quartz and illite-group minerals (Fig. 3b, c). Leucophosphite forms through the reaction between $\mathrm{H}_{3} \mathrm{PO}_{4}$ derived from leached guano and clay minerals in the presence of iron hydroxides (Hill and Forti, 1997). In Gaura cu Muscă, the K and Fe ions were provided by illite-group minerals and iron rich phases, respectively. Leucophosphite was found in several caves in South Africa (Martini, 1987), whereas Cancian and Princivalle (1995) described from Fernetti Cave (Italy) an association formed at the contact between terra rossa and gypsum. In Romania, Dumitraș et al. (2002) have found taranakite and leucophosphite in Lazului Cave.

Taranakite $\left[\mathrm{K}_{3} \mathrm{Al}_{5}\left(\mathrm{HPO}_{4}\right)_{6}\left(\mathrm{PO}_{4}\right)_{2} \cdot 18 \mathrm{H}_{2} \mathrm{O}\right]$ occurs in Gaura cu Muscă and Gaura Haiducească caves as 3-7 cm thick earthy white masses. The XRD and EDS analyses revealed its association with leucophosphite, illite-group minerals and quartz (GM) or with hydroxylapatite and illite-group minerals $(\mathrm{GH})$. In both occurrences the mineral has a high degree of crystallinity as indicated by the X-ray diffractions (Fig. 3b). Under ESEM taranakite appears as pseudohexagonal crystals flattened after the (0001) crystal face (Fig. 5b). Its origin is related to the reaction between bat guano and clay minerals which provide $\mathrm{Al}^{3+}$ and $\mathrm{K}^{+}$ions in an environment with $\mathrm{pH}$ below 7 (Murray and Dietrich, 1956).

Variscite $\left[\mathrm{AlPO}_{4} \cdot 2 \mathrm{H}_{2} \mathrm{O}\right]$ was revealed by X-ray diffraction in the samples collected from an interbedded guano/clay sequence in Gaura cu Muscă Cave (Fig. 3d). The reaction between phosphate-rich leachates derived from bat guano and the underlying clay sediments is at the origin of this phosphate mineral (Onac et al., 2004).

\section{DISCUSSION AND CONCLUSIONS}

Phosphate minerals from three caves in Romania have been investigated in order to decipher the local environmental conditions during their formation. The mineral associations are different in the three caves, with hydroxylapatite the only common element in the three associations studied: in Gaura cu Muscă, the minerals identified are taranakite, leucophosphite, hydroxylapatite and variscite; out of these, only taranakite and hydroxylapatite are present in Gaura Haiducească, whereas the association from Zidită Cave comprises only brushite and hydroxylapatite. The occurrence of these phosphate minerals highlights the decomposition of bat guano in time and the variation of the environmental conditions (mainly changes in $\mathrm{pH}$ and moist vs dry) in the vicinity and within the accumulation.

Calcium phosphates (brushite and hydroxylapatite) originate due to the reaction of phosphate rich solutions with carbonatic rocks and indicate variations of the $\mathrm{pH}$ (acidic, alkaline respectively) and relative humidity of the environment as well as an increase in $\mathrm{Ca} / \mathrm{P}$ ratio towards apatites (Fiore and Laviano, 1991; Onac and Vereş, 2003). The presence of $\mathrm{Fe}^{3+}, \mathrm{K}^{+}$, and $\mathrm{Al}^{3+}$ ions derived from clay minerals or iron hydroxides has led to the precipitation of common phosphates 
a

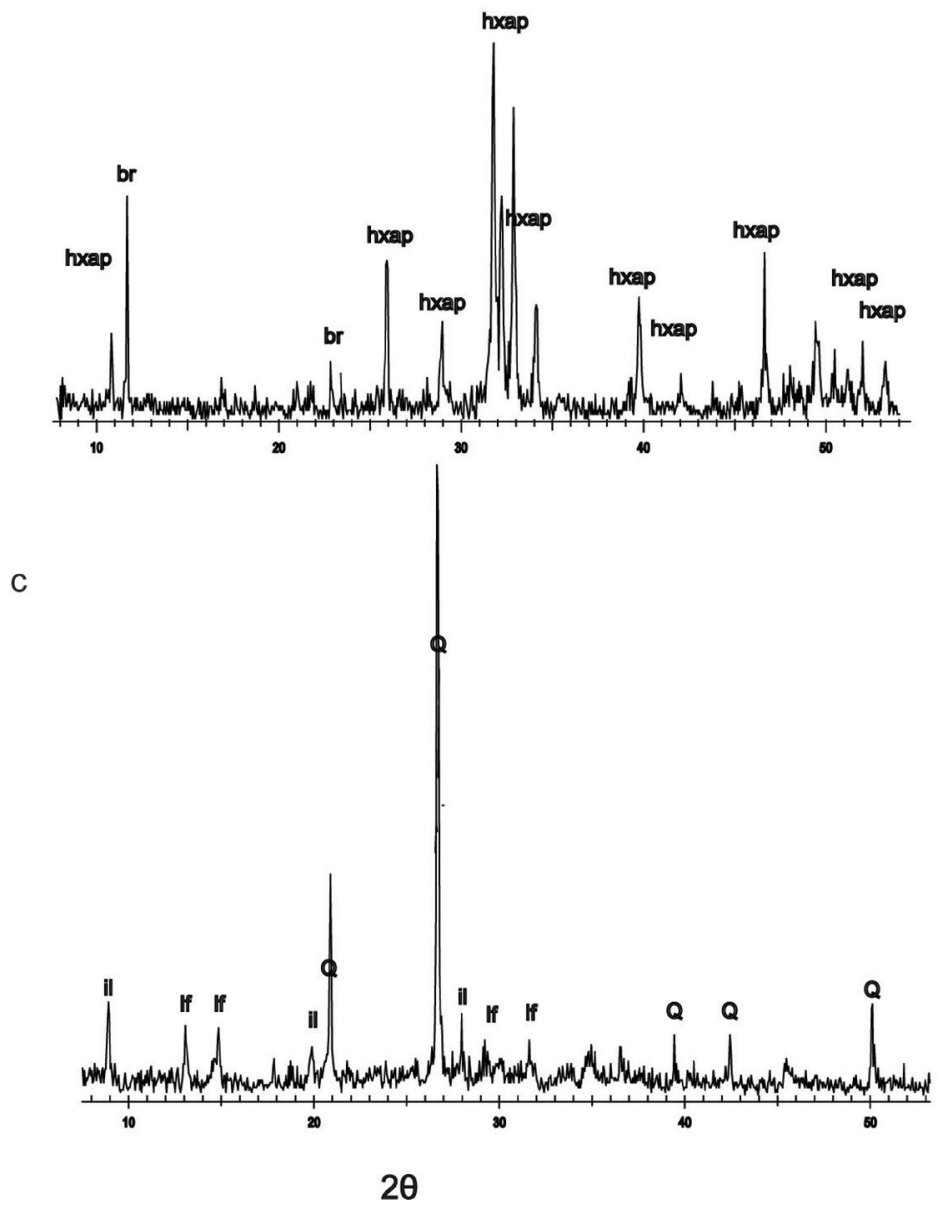

b

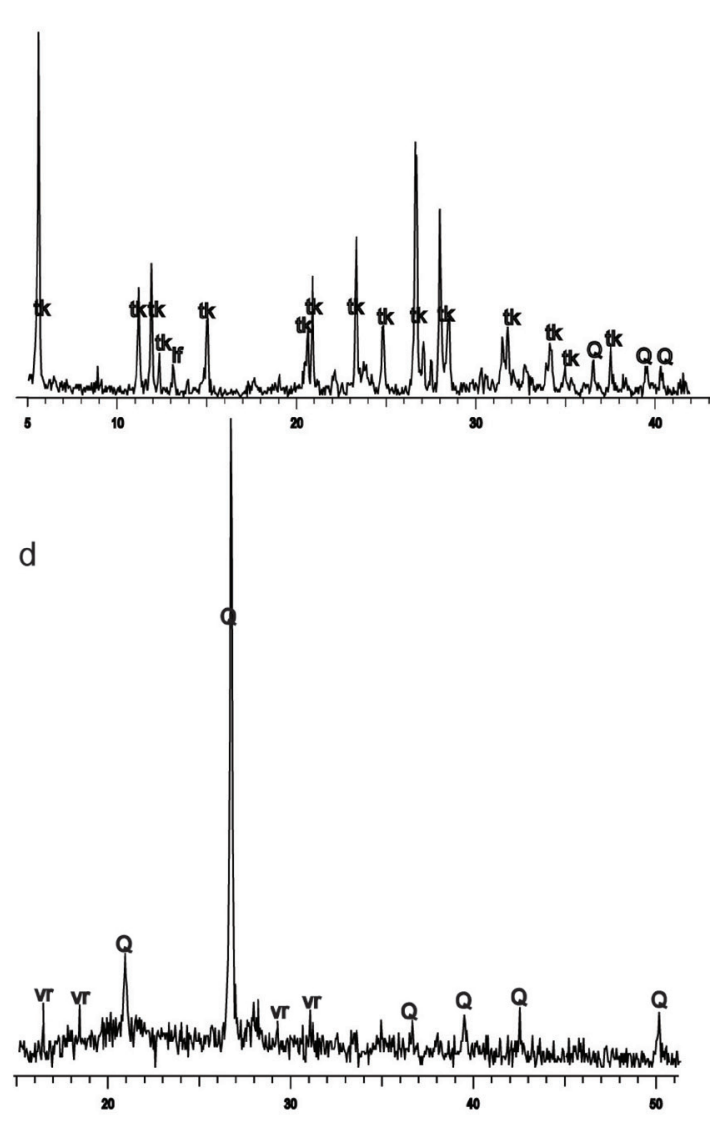

$2 \theta$

Fig. 3. X-ray diffractions of: a) hydroxylapatite and brushite (ZC); b) taranakite (GM); c) leucophosphite (GM); d) variscite (GM).
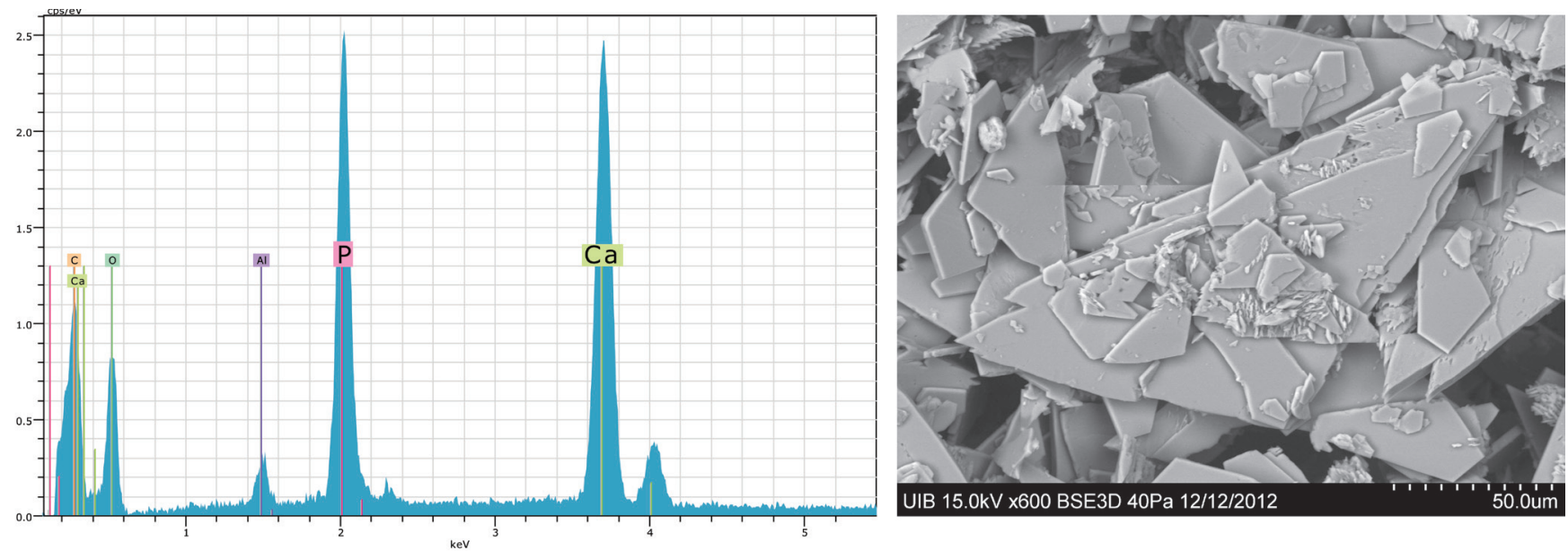

Fig. 4. ESEM image and EDS spectrum of brushite (ZC).

such as taranakite and variscite, which are stable under acidic environmental conditions, or not so common phosphates such as leucophosphite (Fig. 6).

In Gaura cu Muscă, the phosphate minerals show different abundances and indicate two distinct environments, acidic and alkaline, respectively. Leucophosphite and taranakite form in acidic and damp conditions in the presence of $\mathrm{K}^{+}$and $\mathrm{NH}_{4}^{+}$ions (Axelrod et al., 1952). Variscite is stable in solutions free of $\mathrm{K}^{+}$ and $\mathrm{NH}_{4}^{+}$ions and results due to the reaction between bat guano leachates and clay minerals at an acidic $\mathrm{pH}$ (Cole and Jackson, 1950; Onac et al., 2004). Hydroxylapatite precipitates in drier conditions, at high $\mathrm{Ca} / \mathrm{P}$ values and $\mathrm{pH}>6.93$ (Elliot et al., 1959).
Brushite occurs in Zidită Cave where it is the most abundant phosphate mineral, indicating a wet and slightly acidic environment. Considering the experiments carried out by Elliot et al. (1959) on urine with low $\mathrm{Ca} / \mathrm{P}$ ratio it may be assumed that the maximum nucleation $\mathrm{pH}$ of brushite was 6.93. Brushite may form at $\mathrm{pH}>6$ when $\mathrm{Mg} / \mathrm{Ca}$ ratio is about 4, concentration which supposedly inhibits hydroxylapatite precipitation. According to Abbona and Franchini-Angela's (1990) experiments, the brushite-hydroxylapatite association forms from initial solutions with low concentration of $\mathrm{Ca}$ and $\mathrm{P}(0.005 \mathrm{M})$ and initial $\mathrm{pH}$ values between 5.5 and 8 . This process involves the decrease of $\mathrm{pH}$ and starts with the precipitation of unstable mineral phases, which subsequently evolve to more 

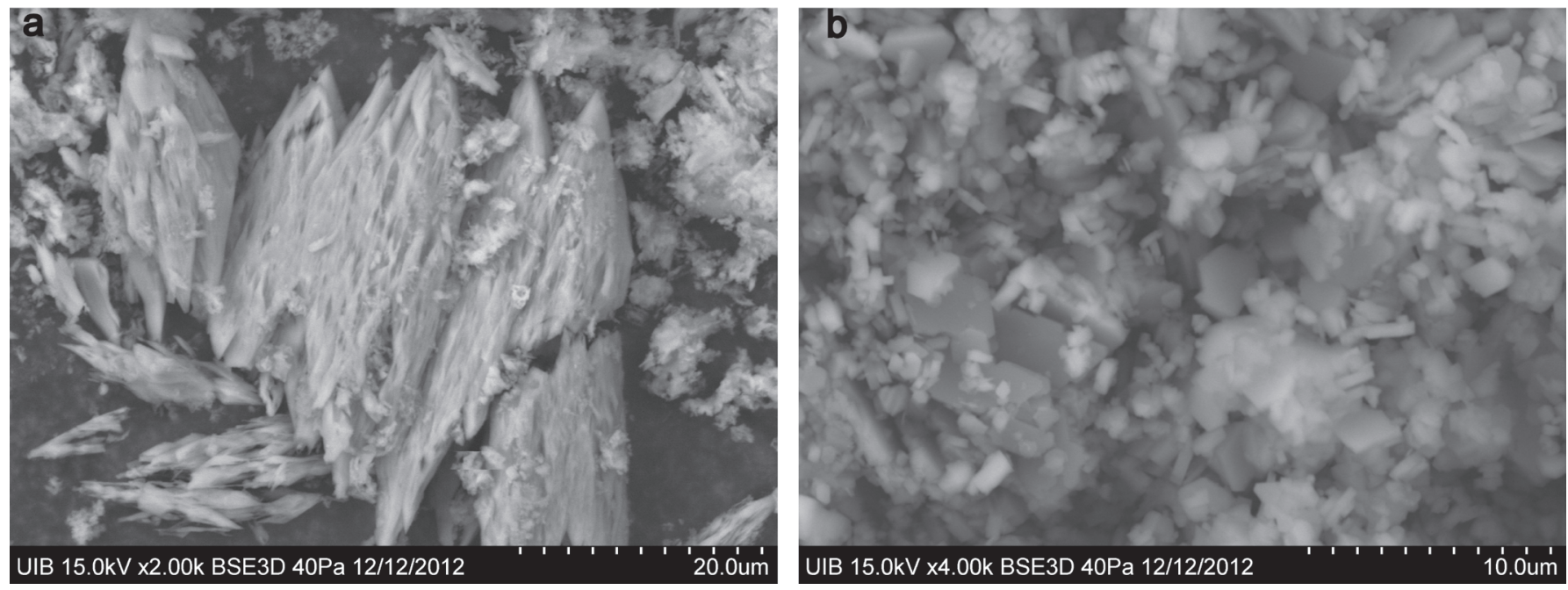

Fig. 5. ESEM images of hydroxylapatite (GH) and taranakite (GM) crystals.

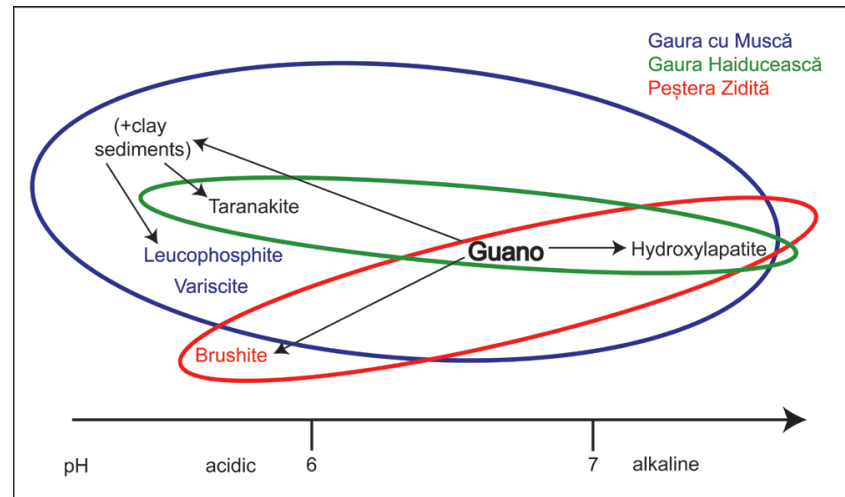

Fig. 6. The $p H$ conditions in which the studied phosphate minerals precipitate.

stable phases. The first to form are brushite and an amorphous calcium phosphate, followed by the conversion of the latter to hydroxylapatite (if $\mathrm{Mg} / \mathrm{Ca}<0.4$ ) or to whitlockite (if $\mathrm{Mg} / \mathrm{Ca}>0.4$ ) (Abbona and Franchini-Angela, 1990). Whitlockite was not found in samples from Zidită Cave and we assume that $\mathrm{Mg} / \mathrm{Ca}$ ratio in the solutions, which interacted with the organic material was low or 0 .

In Gaura Haiducească the $\mathrm{pH}$ variation is more or less similar to that from Zidită Cave. The difference between the two caves is given by the presence of taranakite, which indicates the presence of alkali ions derived from the decomposition of illite-group minerals, at acidic and also higher humidity conditions.

The phosphate minerals described provide information about the environment in which they have formed. In Zidită Cave brushite is the most common phosphate mineral suggesting an overall acidic and damp depositional environment. In Gaura Haiducească the same acidic environmental conditions but much wetter are inferred from the abundance of taranakite. Phosphate minerals from Gaura cu Muscă have different abundances, with taranakite, variscite, and leucophosphite indicating a wet, acidic environment in the proximity of the guano deposits. Hydroxylapatite occurs mainly at distant locations from the large guano accumulations in sections of the cave where only small size colonies are hibernating. Its presence indicates slightly alkaline and drier conditions.

Acknowledgements. The authors would like to thank Paolo Forti and Jacques Martini for their diligent reviews, and Joan J. Fornós, Ferran Hierro, and Joan Cifre from the Serveis Científicotècnics at the Universitat de les Illes Balears in Palma (Spain) for their support while conducting the XRD, ESEM, and EDS analyses.
Ioan Coroiu from the Babeș-Bolyai University (Cluj-Napoca, Romania) is thanked for identifying the bat species from the caves. We thank T. Brad and I. Vişan for helping during the field work activities. R. Breban (Proteus Caving Club, Hunedoara) and S. Constantin kindly provided the maps of Zidită Cave and of Gaura Haiducească, respectively. Tudor Tămaș acknowledges financial support from the Romanian National Authority for Scientific Research, grant PCE-2011-3-0588.

\section{REFERENCES}

Abbona, F., Franchini-Angela, M. 1990, Crystallization of calcium and magnesium phosphates from solutions of low concentration. Journal of Crystal Growth, 104: 661-671. http://dx.doi.org/10.1016/0022-0248(90)90009-A

Axelrod, J.M., Carron, M.K., Milton, C. \& Thaver, T.P. 1952, Phosphate mineralization at Bomi Hill and Bambuta, Liberia, West Africa. American Mineralogist, 37 (11-12): 883-909.

Balintoni, I. 1997, Geotectonics of the metamorphic terraines from Romania. Editura Carpatica, Cluj-Napoca, 176 p. (in Romanian).

Balintoni, I. Balica, C., Ducea, M.N., Chen, F., Hann, H.P. \& Șabliovschi, V. 2009, Late Cambrian-Early Ordovician Gondwanan terranes in the Romanian Carpathians: A zircon U-Pb provenance study. Gondwana Research, 16: 119-133. http://dx.doi.org/10.1016/j.gr.2009.01.007

Bleahu, M., Decu, V., Negrea, St., Pleşa, C., Povară, I. \& Viehmann, I. 1976, The caves of Romania, Editura Știinţifică şi Enciclopedică, București, 415 p (in Romanian).

Boroneanț, V. 2000, Archaeology of the caves and mines from Romania. cIMeC- Institutul de Memorie Culturală, București, 355 p (in Romanian).

Bucur, I. 1997, The Mesozoic formations from Reșița-Moldova Nouă Area (Aninei Mountains and Eastern Locvei Mountains). Presa Universitară Clujeană, Cluj-Napoca, 214 p (in Romanian).

Cancian, G., Princivalle, F. 1995, La Leucofosfite nell'abisso di Fernetti (Carso triestino). Bolletino de la Societa Adriatica di Scienze, LXXVI: 5-15.

Cocean, P. 1988, Gorges and defiles from Apuseni Mountains. Editura Academiei RSR, 166 p (in Romanian).

Cole, C.V., Jackson, M.L. 1950, Colloidal dihydroxy dihydrogen phosphates of aluminum and iron with crystalline character established by electron and X-ray diffraction. Journal of Physical Chemistry, 54 (1): 128-142. http://dx.doi.org/10.1021/j150475a011 
Dumitraş, D.G., Marincea, Ş. \& Diaconu, G. 2002, Leucophosphite and taranakite in the bat-guano deposit from Lazului Cave (Mehedinți Mountains). Romanian Journal of Mineral Deposits, 80: 23-25.

Elliot, J.S., Sharp, R.S. \& Lewis, L. 1959, The effect of the molar $\mathrm{Ca} / \mathrm{P}$ ratio upon the crystallization of brushite and apatite. Journal of Physical Chemistry, 63: 725-726. http://dx.doi.org/10.1021/j150575a020

Fiore, S., Laviano, R. 1991, Brushite, hydroxylapatite, and taranakite from Apulian caves (southern ltaly): New mineralogical data. American Mineralogist, 76: 1722-1727.

Frost, R., Palmer, S. 2011, Thermal stability of the 'cave' mineral brushite $\mathrm{CaHPO}_{4} \cdot 2 \mathrm{H}_{2} \mathrm{O}-$ Mechanism of formation and decomposition. Thermochimica Acta, 521 (1-2): 14-17. http://dx.doi.org/10.1016/j.tca.2011.03.035

Hill, C., Forti, P. 1997, Cave minerals of the world ( $2^{\text {nd }}$ ed.). National Speleological Society, Huntsville, Alabama, 464 p.

Iurkiewicz, A. 2010, Banat Mountains (Reșița-Moldova Nouă synclinorium). In Karst hydrogeology of Romania (Orășeanu, I., Iurkiewicz, A., Eds.), Belvedere Publishing House, Oradea, p. 137-168.

Iurkiewicz, A., Constantin, S. \& Bădescu, B. 1996, Major karstic systems from the Reşiţa-Moldova Nouă area. A.S. Exploratorii Reşiţa, 70 p (in Romanian).

Mantea, G., Tomescu, C. 1986, Geological structure of the central area of the Metaliferi Mountains, Balşa-Ardeu-Cib zone. Dări de Seamă ale Institului de Geologie și Geofizică, 70-71 (5) (1983, 1984): 129-148.

Marincea, Ș., Dumitraș, D.G., Diaconu, G. \& Bilal, E. 2006, Mineralogical data on the bat guano deposit from Polovragi Cave (Căpățânii Mountains, Romania). Acta MineralogicaPetrographica, Abstract Series, 5: 71.

Martini, J.E. 1987, Contribution to the mineralogy of Cango caves. South African Speleological Association Bulletin, 28: 18-28.

Murray, J.W., Dietrich, R.V. 1956, Brushite and taranakite from Pig Hole Cave, Giles Co., Virginia. American Mineralogist, 41: 616-626.

Negrea, S,., Negrea, A. 1969, The caves from the Danube Gorge. Travaux de l'Institut de Spéologie «Emil Racovitza», 8: 25-50 (in Romanian).
Negrea, A., Negrea, Ş. 1979, The caves from the Danube Gorge and their terrestrial fauna. In Speologia (Orghidan, T., Negrea, Ş., Eds.), Editura Academiei RSR, București, p. 30-75 (in Romanian).

Onac, B.P. 2012, Minerals. In Encyclopedia of Caves (2 $2^{\text {nd }}$ Edition) (White, W.B., Culver, D.C., Eds.), Chennai: Academic Press, p. 499-508.

http://dx.doi.org/10.1016/B978-0-12-383832-2.00072-4

Onac, B.P., Forti, P. 2011a, State of the art and challenges in cave minerals studies, Studia UBB Geologia 56 (1): 33-42. http://dx.doi.org/10.5038/1937-8602.56.1.4

Onac, B.P., Forti, P. 2011b, Minerogenetic mechanism occurring in the cave environment: an overview. International Journal of Speleology, 40 (2): 79-98. http://dx.doi.org/10.5038/1827-806X.40.2.1

Onac, B.P., Vereş, D.S. 2003, Sequence of secondary phosphates deposition in a karst environment: evidence from Măgurici Cave (Romania). European Journal of Mineralogy, 15: 741-745. http://dx.doi.org/10.1127/0935-1221/2003/0015-0741

Onac, B.P., Kearns, J., Breban, R. \& Cîntă Pânzaru, S. 2004, Variscite $\left(\mathrm{AlPO}_{4} \cdot 2 \mathrm{H}_{2} \mathrm{O}\right)$ from Cioclovina Cave (Şureanu Mountains, Romania): A tale of a missing phosphate. Studia UBB Geologia, 49 (1): 3-14.

Onac, B.P., Zaharia, L., Kearns, J. \& Vereș, D. 2006, Vashegyite from Gaura cu Muscă Cave. International Journal of Speleology, 35 (2): 67-73. http://dx.doi.org/10.5038/1827-806X.35.2.2

Orășeanu, I. 2010, Upper watershed of Geoagiu River (The Metaliferi Mountains). In Karst hydrogeology of Romania (Orășeanu, I., Iurkiewicz, A., Eds.), Belvedere Publishing House, Oradea, p. 311-315.

Povară, I., Horoi, V. 1993, Morpho-hydrographic and hydrogeological observations in the limestone area from the south-eastern Metaliferi Mountains (Romania). Theoretical and Applied Karstology, 6: 181-187.

Tămaș, T., Ungureanu, R. 2010, Mineralogy of speleothems from four caves in the Purcăreţ-Boiu Mare Plateau and the Baia Mare Depression (NW Romania). Studia UBB Geologia, 55 (2): 43-49. http://dx.doi.org/10.5038/1937-8602.55.2.3 